This content is available online at AESA
e-ISSN: $2456-6632$

\title{
Simulating the effects of human urine on phenology and some cultivar coefficients of Cowpea (Vigna unguicalata L. Walp) using the DSSAT-CROPGRO model
}

\section{David Lomeling* (D) and Salah Joseph Huria}

Department of Agricultural Sciences, CNRES, University of Juba. P.O. Box 82 Juba, South SUDAN

${ }^{*}$ Corresponding author's E-mail: dr.david_lomeling@gmx.net

\section{ARTICLE HISTORY}

Received: 08 November 2019

Revised received: 22 November 2019

Accepted: 22 November 2019

\section{Keywords}

Cultivar coefficients

Human urine

Leaf area index

Phenology

Pod number

\section{ABSTRACT}

The DSSAT-CROPGRO model was used to characterize phenology and cultivar coefficients of cowpea treated with diluted human urine (equivalent to $60 \mathrm{~kg}-\mathrm{N} / \mathrm{ha}$ ), simulated under ten irrigation schedules for a 5 year production period in Juba County of Central Equatoria State, South Sudan. Two treatments $\left(T_{0}\right)$ without urine and $\left(T_{1}\right)$ with human urine dilution during the growing season of 2016 were used and, 5-years model simulations on the grain number $/ \mathrm{m}^{2}$, LAl, canopy height $(\mathrm{m})$ and pod number $/ \mathrm{m}^{2}$ compared. Irrigation schedules were carried out once the volumetric soil moisture content measured using the Theta Soil Moisture Probe was close to $15 \%$. Results showed that cultivar coefficients EM-LF, FL-LF and FL-SH for both $\mathrm{T}_{0}$ and $\mathrm{Y} 2015$ (calibrant) were on average 6-8 days shorter than under $\mathrm{T}_{1}$. Also, the SIZLF under $\mathrm{T}_{1}$ was about 8-17\% greater than under both $\mathrm{T}_{0}$ and calibrant Y2015 indicating the significance of diluted human urine on cowpea cultivar coefficients and phenology. The model also gave good agreement between observed and simulated growth parameters with low RMSE of the pod $\mathrm{nr} / \mathrm{m}^{2}$ at 17 for $\mathrm{T}_{0}$, and 37.5 for $\mathrm{T}_{1}$, the RMSE for grain $\mathrm{nr} / \mathrm{m}^{2}$ was $360 \mathrm{~kg}$ for $T_{1}$, and $347 \mathrm{~kg}$ for $T_{0}$, whereas the RMSE of LAl showed no significant difference. The $d$-indices in estimating LAl and canopy height were generally low and showed the largest errors than for pod $\mathrm{nr} / \mathrm{m}^{2}$ and grain $\mathrm{nr} / \mathrm{m}^{2}$. The results showed that the model satisfactorily simulated and underscored the significance of diluted human urine on both phenology and cultivar coefficients of cowpea.

(C)2019 Agriculture and Environmental Science Academy

Citation of this article: Lomeling, D. and Huria, S.J. (2019). Simulating the effects of human urine on phenology and some cultivar coefficients of Cowpea (Vigna unguicalata L. Walp) using the DSSAT-CROPGRO model. Archives of Agriculture and Environmental Science, 4(4): 369-378, https://dx.doi.org/10.26832/24566632.2019.040402

\section{INTRODUCTION}

Cowpea is one the major food crops in Central Equatoria State of South Sudan and an indispensable source of cheap and easily available plant protein. The young and tender leaves are consumed traditionally as nete while the ripened and mature seeds as pirinda (Lomeling and Abbass, 2014). In the presence of irrigation water, cowpea can be produced in small farms or household backyards during any time of the year. It is a highly remunerative crop with price increase several times its normal value especially during the annual "hunger spells" of mid-July to Mid-August. However, increasing price of potable water and the large influx of Internally Displaced Persons (IDPS) due to current civil war, cowpea production per household has significantly decreased within and around Juba municipality. Similarly, cowpea production, as a cheap source of plant protein, is not only threatened by a reduced availability of irrigation water but also declining soil fertility caused increased and excessive removal of soil nutrients as well as reduction in soil functional properties (Lomeling et al., 2016a). As a drought resistant plant, reduced irrigation is not necessarily a limiting factor, since soil moisture requirements during cowpea phenology show temporal variability between 15-30\% (Lomeling et al., 2016b). However, soil moisture contents $<15 \%$ at any one developmental stage of growth has adverse effects on the germination rate, flowering, canopy height, pod-setting and maturity (Abayomi 
and Abidoye, 2009; Suliman and Ahmed, 2010; Souza et al., 2017). Reduction in cowpea yield is not only attributable to insufficient soil moisture during growth, but also to such abiotic stress factors like phosphate (P) deficiency (Goufo et al., 2017; Jemo et al., 2017; Fatokun et al., 2012; Agele et al., 2018). Although Eutric leptosols are the major soil type around Juba County and can be perceived to be of moderate to good fertility, sustained cultivation over longer period without any concerted soil amendments may ultimately pose serious soil fertility challenges. The use of composted tannery sludge was found to sustain cowpea yield during a six-year period (Araújo et al., 2016); increased cowpea yield after application of biochar in loamy sand soil (Pudasainia et al., 2016); increased cowpea biomass after addition of nitrogen fertilizers (Hasan et al., 2010).

There's much literature on the use of cow dung organic matter as a soil ameliorant (Adekiya et al., 2017; Nweke and Nsoanya, 2015; Nyatuame and Nartey, 2013; Tekwa et al., 2010). However, current published data on the application of human urine (Sene et al., 2013; Ranasinghe et al., 2016; Tampio et al., 2016) as a viable fertilizer option are derived from short term studies and are insufficient to adequately assess the agronomic, economic and environmental implications. Human urine in diluted form can successfully be applied as an optional fertilizer for plant growth (Andersson, 2016). However, one critical risk component in the widespread use of human urine across many developing countries of Sub-Sahara Africa would be the local and regional water scarcity. Water scarcity compounded by the erratic spatial and temporal rainfall distribution variabilities would make its use difficult or outright impossible. Thus, it is imperative, that knowledge on the spatial and temporal water availability and accessibility for most smallholder farmers who practice rainfed agriculture, be integrated into the respective country agricultural policies and implementation programs when evaluating the use of human urine. Moreover, farmers' willingness to adopt the use of human urine will depend not only on the available infrastructure in terms of hygienic storage, transportation and dosing, but also on the anticipated increased yields and profitability. Indeed, human urine is a cheap, readily available and considered as a stopgap option for subsistence farmers for whom subsidized industrial fertilizers are often not available, unaffordable and inaccessible. Such an intervention with human urine would not only achieve some annual yield increase to cater for immediate household food needs but also consolidate food security in terms of availing the daily needed cash flow.

To address the sustainable use of human urine as an environmentally and ecologically viable option for most households in Sub Sahara Africa, systematic research and long-term field tests need to be carried out and simulations conducted with dynamic crop models such as the CROPGRO of the DSSAT (Jones et al., 2003; Zinyengere et al., 2015). Not only can the model be used to assess crop yield and economic returns for a range of different soil and water management strategies, but also to assess environmental impacts in terms of nitrogen loads leached into groundwater as a result of excessive human urine application. Unlike most field trials that describe the causality between fertilizer application amounts and yield, no studies have so far attempted to model crop response to human urine application and dosing.

The application of DSSAT-CROPGRO model for cowpea is therefore an indispensable ex ante analysis tool. The CROPGRO module has been successfully demonstrated across a broad range of soil, management and climatic conditions in tropical environments (Banterng et al., 2010; Lomeling et al., 2014; Bastos et al., 2002; (Nkulumo et al., 2015).

It also can be used to assess the type of promising or similar climate smart technologies whose "low scale" investments are not only remunerative, but also financially affordable as is the case for most smallholder farmers in South Sudan (Singh et al., 2016). Model projections during simulations can be used as basis for long-term actionable trends in terms of assessing food demand and agricultural production based on projected changes in population, income, technology, and climate (Robinson et al., 2015). Examples on the use of CROPGRO models have been reported in several studies on bean by Oliviera et al., 2012); on safflower by (Singh et al., 2016); on faba bean by (Boote et al., 2002); on peanut by (Halder et al., 2017).

For most smallholder farmers in South Sudan, the erratic rainfall patterns experienced every year prior and during each planting season are inexplicable weather phenomena. However, most farmers do acknowledge a gradual shift in both amounts, patterns and intensity of rainfall over the last 20 to 30 years. Generally, the recent rainfall forecasts reported for example by (FEWSNET, 2018) within the East African region, are mostly limited to short-term one to three months lead time. South Sudan still lacks a good infrastructure, network of weather stations as well as skilled personal to capture and store weather data in real-time. The absence of such important historical weather data therefore makes any long-term predictions on rainfall occurrence, amounts and intensity difficult. The CROPGRO model requires daily, monthly or annual rainfall amounts as an input variable, thus, simulation of crop yield for most parts of South Sudan in the absence of such relevant data may simply be a speculative exercise.

In our study, we sought to simulate the response of cowpea to human urine application under irrigation conditions using DSSAT-CROPGRO model on phenology, yield and some cultivar coefficients. This study is a novelty and the first of its kind in South Sudan and a further step towards scientifically consolidating the application of human urine as a viable organic fertilizer alternative. Furthermore, the paper tries to address the question, whether or, not simulation will expand our understanding of plant-fertilizer interactions and how this could eventually be integrated in cowpea crop production systems.

The simulation reported in this study is one of the first studies in South Sudan applying the CROPGRO-DSSAT model for evaluating the effects of human urine (as an organic fertilizer) application on crop phenology and yield. Furthermore, the paper tries to address the question, whether or, not simulation will expand our understanding of plant-fertilizer interactions and how this could eventually be integrated in cowpea crop production systems. 


\section{MATERIALS AND METHODS}

\section{Study region}

The experimental study was conducted as from May till September 2015 at the Demonstration and Research Plots of the Department of Agricultural Sciences, University of Juba. The study area is located in Juba County, Central Equatoria State at $4^{\circ} 51^{\prime} 33 \mathrm{~N}$ latitude, $31^{\circ} 34^{\prime} \mathrm{E}$ longitude and at elevation of about $500 \mathrm{~m}$ above sea level. The climate is sub-tropical with mean annual rainfall of $800-1200 \mathrm{~mm}$ and a predominantly unimodal distribution. About $80-90 \%$ of the rainfall occurs during the rainy months (April-October) with a short dry spell around July. The soil (Eutric leptosol) is sandy loam in texture, mild acidic to alkaline in reaction ( $\mathrm{pH} 6.5-7.5)$, low organic carbon by weight (0.55\%), CEC in soil (14 cmol/kg) (Table 1, 2).

\section{Experimental design and treatments}

The experiment was a Randomized Complete Block Design (RCBD) with two different treatments with five replications each and was conducted from May to September 2015. Each trial was arranged in four randomized complete blocks. Traditional agricultural practices of tillage, seed bed preparation and pest control against aphids, grasshoppers, leaf sucking bugs using ashes from burnt plant leaves were applied. Occasionally, a broad-spectrum pesticide Malathion with application rate of $0.5 \mathrm{I} /$ ha was applied, where the traditional pest control method proved ineffective. Each plot consisted of 5 rows, $2.5 \mathrm{~m}$ long, with a spacing of $30 \mathrm{~cm}$ between plants and $50 \mathrm{~cm}$ between rows. The size of each plot was $5.4 \mathrm{~m}^{2}$ with seeds drilled at a sowing depth of $5 \mathrm{~cm}$ and density of 30 plants $/ \mathrm{m}^{2}$. The control treatment (irrigation water + No human urine) was designated as $T_{0}$ while (irrigation water + human urine: 2 liters per 20 liters water) as $T_{1}$. The calculated $\mathrm{N}$-fertilizer amount from $\mathrm{T}_{1}$ was about $60 \mathrm{~kg} / \mathrm{ha}$. Urine from the test person was collected every two days in a $500 \mathrm{ml}$ plastic bottle and mixed with normal water and later kept in a cool dry place until use. Since the overall composition of urine collected was subject to change depending on the nutritional status of the test person, no analytical test on the chemical composition of the urine samples was conducted. Irrigation under both treatments was done once the soil moisture level reached about $15 \% \mathrm{v} / \mathrm{v}$ and was measured using the Theta Soil Moisture Sensor ML3 (Eijkelkamp Agrisearch). The dates of the different phenological stages, i.e. during each trifoliate stage, from seedling emergence to first flower (EMLF), first flower to end of leaf expansion (R1), pod-setting (FL$\mathrm{SH}$ ), maximum leaf size at 8th trifoliate stage (SIZ-LF), plant canopy height (RHIGHT) were all recorded. Leaf Area Index (LAI) was determined directly by measuring the area of the leaves in a plant foliage at any one vegetative stage relative to the surface area covered by the plant. The average LAI was then expressed as a function of the total leaf area for all plants within a given plot. At harvest, the yield per plot was measured by counting the number of pods per plant, seeds per pod (SDPDV), maximum weight per seed (WTPSD) of randomly selected plants. From these figures the grain yield per plot was calculated and projected for entire hectare.

The required weather data for DSSAT WEATHR module, the WGEN subroutine was run to capture the daily rainfall, minimum and maximum air temperature, solar radiation, relative humidity, and wind speed. For Juba County, these data were obtained from the publicly accessible servers of the National Oceanic and Atmospheric Administration (NOAA) of the US Department of Commerce for the years 1980-2014.

Table 1. Some of the physical and chemical properties of sandy loam soil (Eutric leptosol) at University of Juba Research and Demonstration Farm.

\begin{tabular}{ll}
\hline Soil physical and chemical features & Description \\
\hline Soil mapping unit* & Eutric leptosol \\
Texture Classification & Sandy loam \\
Drainage Class (0-0.5) & Moderately well \\
Sand (average) & $48.9 \%$ \\
Silt (average) & $43.7 \%$ \\
Clay (average) & $7.4 \%$ \\
pH (LaMotte STH Test Method) & 7.0 \\
Nitrate nitrogen & $22.68 \mathrm{~kg} / \mathrm{ha}$ \\
Phosphorus & $170.1 \mathrm{~kg} / \mathrm{ha}$ \\
Sulphate & $1000 \mathrm{ppm}$ (parts per million) \\
Iron & $1.36 \mathrm{~kg} / \mathrm{ha}$ \\
Magnesium & Medium \\
Calcium & $396.9 \mathrm{~kg} / \mathrm{ha}$ \\
Bulk density $\left(\mathrm{gm} / \mathrm{cm}^{3}\right.$ ) & 1.34 \\
Humus content & $2.95 \%$ \\
\hline
\end{tabular}

*Source: Harmonize World Soil Data viewer version 1.2. 
Calculation of cultivar coefficients

The GENCALC program of the Decision Support System for Agrotechnology Transfer (DSSAT Version 4.7) was used to calibrate the cultivar coefficients of the cowpea UCR368 cultivar. GENCALC (Genotype Coefficient Calculator) is a software package that facilitates the calculation of cultivar coefficients for use in existing crop models. Hereby, the coefficients for a genotype are estimated iteratively by running the appropriate crop model with model input data and approximate coefficients, comparing the model output with actual data, and then altering the coefficients until the simulated and measured values match (Hunt et al., 1993). In our study, eight morphological traits were selected and calculated by running GENCALC to obtain the best range i.e., the photothermal days from emergence to first flower (EM-FL), from first flower to end of leaf expansion (FL-LF), from flower beginning to pod setting (FL-SH), maximum size of leaf (SIZ-LF), maximum weight per seed (WTPSD), average seed per pod (or pod nr: SDP-DV), photothermal days from seed beginning to physiological maturity (SD-PM) and relative plant/ canopy height (R-HIGHT).

\section{Model calibration}

The CROPGRO-Cowpea module uses different cultivar coefficients (EM-LF, FL-LF, FL-SH, SIZLF, SDPDV, SD-PM, RHIGHT) amongst others to describe the different phenological stages as a function of time. The CROPGRO-Cowpea model was calibrated for the cowpea cultivar UCR368 with data obtained from May to September 2015 cropping season, to underpin the model's relevance and application in the region under the current prevailing pedogenic, hydrological and climatic conditions. This was iteratively done through a manual trial and error method, to determine the best possible match between the observed and simulated values to the different default morphological traits obtained from previously grown cowpea cultivar. The values were adjusted to have minimum root mean square error (RMSE) between simulated and observed data. In our study, we used four growth parameters; pod $\mathrm{nr} / \mathrm{m}^{2}$, canopy height, Leaf Area Index ( $\mathrm{LAl}$ ) and grain $\mathrm{nr} / \mathrm{m}^{2}$ to evaluate model performance.

\section{Model performance statistics}

Model performance for each morphological trait was assessed by comparing the mean simulated with the corresponding measured values based on the Root Mean Square Error (RMSE) and the Index of Agreement or d-stat (d) (Willmott et al., 2012). It was assumed that the best model performance between simulated and measured values was when it gave the lowest RMSE and correspondingly high $d$-value close to 1 . The RMSE was computed using the following equation:

$$
\text { RMSE }=\sqrt{\sum_{i=1}^{n}\left(P_{i}-O_{i}\right)^{2} / n}
$$

and

$$
d=1-\left[\sum_{i=1}^{n}\left(P_{i}-O_{i}\right)^{2} /\left(\left|P_{i}-\vec{O}_{i}\right|-\mid O_{i}-\vec{O}_{i}\right)^{2}\right]
$$

Where,

$$
0 \leq d \leq 1
$$

Where $n$ : number of observations, Pi: predicted value for the ith observation or measurement and Oi: observed value for the ith measurement, $\vec{O}_{i}$ is the observed mean of all measurements.

Table 2. Relevant default data used to run the phenology of cowpea in a sandy loam soil under different treatments of moisture content.

\begin{tabular}{ll}
\hline Variable & Specification/dimension \\
\hline Variety /Cultivar & UCR368 \\
Planting date & $14 / 5 / 2015$ \\
Emergence date & $18 / 5 / 2015$ \\
Plants/ plot & 20 \\
Planting depth & $0.03 \mathrm{~m}$ \\
Seeds/hole & 2 \\
Planting spacing & $0.3 \mathrm{~m}$ \\
Row spacing & $0.5 \mathrm{~m}$ \\
Rain fall & depending on rainfall regularity \\
Plot area & $5.4 \mathrm{~m}^{2}$ \\
Irrigation schedule & Flooding once the soil moisture content was $<15 \% \mathrm{v} / \mathrm{v}$ \\
\hline
\end{tabular}




\section{RESULTS AND DISCUSSION}

\section{Cultivar coefficients}

Table 3 shows the result of the comparison of observed values during phenology calibrated against those of 2015. The observed times for the genetic coefficient (EM-LF) for $T_{0}$ was 4 photothermal days (PD) shorter, but for $\mathrm{T}_{1}$ was 5 days longer than the calibrated value of 2015. The observed EM-LF for $T_{1}$ treatment showed the highest value than either $\mathrm{T}_{0}$ treatment or calibrated value of 2015 (irrigation schedules without urine addition). The effect of human urine ( $\left.T_{1}\right)$ appeared to enhance further vegetative growth thus extending the photoperiod to the onset of first flowers. Meanwhile, the observed times for FLLF was between -6 and +16 PD compared to the calibrated value of 2015 were higher and showed similar effect of human urine $\left(T_{1}\right)$ on $\mathrm{R} 1$ and leaf expansion. For FL-SH, these were +4 photothermal days for $T_{1}$ than either $T_{0}$ or the calibrated 2015 value. The difference between observed maximum leaf area attained at the $8^{\text {th }}$ trifoliate stage (SIZLF) varied between -9 and -14 PD to the 2015 calibrated value. The WTPSD, SDPDV, SD$\mathrm{PM}$ and RHIGHT all showed similar trends of $\mathrm{T}_{1}$ values higher than either $\mathrm{T}_{0}$ or the calibrated 2015 value.

Comparisons of the cultivar coefficients between $T_{0}, T_{1}$ and the Y2015 calibrant showed that both $T_{0}$ and Y2015 calibrant had about 6-8 days shorter EM-LF than $T_{1}$, suggesting that under $T_{1}$, the plants required more days for vegetative growth prior to the start of the reproductive phase. A similar tendency was observed for the FL-LF and FL-SH traits that varied between 56 days respectively. The SIZLF by $T_{1}$ was relatively larger and varied between 8 to $17 \%$ more than both $T_{0}$ and $Y 2015$ calibrant. There was no significant difference $(p<0.05)$ in the WTPSD under both treatments as well as with the calibrant, but rather in the number of seeds per pod that was slightly higher in $T_{1}$ than either $T_{0}$ or $Y 2015$. Although both treatments were subjected to equal and timely irrigation schedules, the longer vegetative expansion process resulting into elongated nodes, larger leaf size and subsequently greater canopy height in $T_{1}$ than $T_{0}$ is attributable to the effects of $\mathrm{N}$-contained in the diluted urine. On the contrary, $\mathrm{T}_{0}$ had lesser vegetative growth, smaller SIZLF, lower RHIGHT, SDPDV and consequently lesser amount of accumulated dry matter. From an agronomical and plant physiological perspective, $T_{0}$ appears to have low determinacy than $T_{1}$. Under $T_{1}$ with larger SIZLF, there was presumably greater partitioning and accumulation of dry matter to the reproductive organs as shown by the relatively larger WTPSD and SDPDV (Table 3) which subsequently would give higher yield. Although the cowpea UCR368 is considered as a determinate cultivar, the physiological and phenological changes in the morphological traits induced by $\mathrm{N}$-addition give it an indeterminate growth character.

Table 3. Some of the coefficients of cowpea cultivar UCR368 used during calibration and validation. (Irrigation was done, when moisture content was less than $15 \% \mathrm{v} / \mathrm{v})$.

\begin{tabular}{|c|c|c|c|c|}
\hline \multirow{3}{*}{$\begin{array}{l}\text { Cultivar } \\
\text { coefficient }\end{array}$} & \multirow{3}{*}{ Description } & \multicolumn{3}{|c|}{ Coefficient values } \\
\hline & & \multicolumn{2}{|c|}{2016} & \multirow{2}{*}{2015} \\
\hline & & TO & T1 & \\
\hline EM-LF & Time (days) between seedling emergence and first flower & 42 & 48 & 40 \\
\hline FL-LF & Photothermal days (PD) between first flower (R1) and end of leaf expansion & 27 & 32 & 20 \\
\hline FL-SH & Photothermal days from beginning flower to pod setting & 6 & 12 & 7 \\
\hline SIZLF & Maximum size of full leaf in $\left(\mathrm{cm}^{2}\right)$ at $8^{\text {th }}$ trifoliate stage & 38.4 & 46.5 & 42.7 \\
\hline WTPSD & Maximum weight (gm) per seed & 0.11 & 0.2 & 0.13 \\
\hline SDPDV & Average seeds per pod (\#nr) under standard growing conditions & 14 & 16 & 11 \\
\hline SD-PM & Photothermal days from beginning seed to physiological maturity & $72-77$ & $76-81$ & $60-66$ \\
\hline RHIGHT & Relative plant/canopy height (cm) & $62-72$ & $68-79$ & $61-68$ \\
\hline
\end{tabular}

Table 4. Growth and yield parameters of cowpea cultivar UCR368 under different treatments during a 5-year simulation period.

\begin{tabular}{|c|c|c|c|c|c|}
\hline \multirow{2}{*}{ Growth and yield parameters } & \multirow{2}{*}{ Error and $d$-index values } & \multicolumn{2}{|c|}{$\mathrm{T}_{0}$} & \multicolumn{2}{|c|}{$\mathrm{T}_{1}$} \\
\hline & & Year 1 & Year 5 & Year 1 & Year 5 \\
\hline \multirow{2}{*}{ Pod $n r / m^{2}$} & RMSE & 17.3 & 16.8 & $38.8^{* *}$ & $36.1^{* *}$ \\
\hline & $d$ & 0.46 & 0.36 & $0.54^{* *}$ & 0.48 \\
\hline \multirow{2}{*}{ LAI } & RMSE & 0.19 & 0.18 & 0.22 & 0.28 \\
\hline & $d$ & 0.36 & 0.36 & $0.18^{* *}$ & 0.34 \\
\hline \multirow{2}{*}{ Grain nr/m² } & RMSE & 345 & $374^{* *}$ & 351 & 343 \\
\hline & $d$ & 0.81 & 0.70 & $0.52^{* *}$ & 0.71 \\
\hline \multirow{2}{*}{ Canopy height (m) } & RMSE & 0.23 & 0.23 & 0.25 & 0.26 \\
\hline & $d$ & 0.18 & 0.36 & 0.33 & 0.36 \\
\hline
\end{tabular}

${ }^{* *}$ significant at $\mathrm{p}<0.05$. 
Phenological parameters

Comparisons of phenology parameters between predicted and observed values for Year1 and Year 5 simulations were based on RMSE and $d$-values for both $\mathrm{T}_{0}$ and $\mathrm{T}_{1}$ treatments. On average, simulations of the Pod $\mathrm{nr} / \mathrm{m}^{2}$ for $\mathrm{T}_{1}$ treatment for Years 1 and 5 showed RMSE values that were between $53-55 \%$ higher than $T_{0}$ in the respective years (Table 4). The model showed better performance in simulating Pod $\mathrm{nr} / \mathrm{m}^{2}$ for $\mathrm{T}_{1}$ than $\mathrm{T}_{0}$. On the other hand, the Willmott $d$-index for Pod $\mathrm{nr} / \mathrm{m}^{2}$ for $\mathrm{T}_{1}$ treatment was significantly different with about $33 \%$ difference to $T_{0}$ for the simulation period. The RMSE for LAl for both treatments showed no significant differences during the simulation period except for Year 1 under $T_{0}$. The model showed poor performance in simulating LAI in Year 1 under $T_{1}$ than in $T_{0}$ which on average showed relatively low $d$-index at about 0.35 . This may be more of an experimental error than a phenological attribute. However, there was significant difference for the RMSE for Grain $\mathrm{nr} / \mathrm{m}^{2}$ in treatment $\mathrm{T}_{0}$ for Year 5 simulation, with about 7.7\% difference to Year 1 under the same treatment conditions and on average $7.2 \%$ more than under $\mathrm{T}_{1}$ treatment. For the canopy height, both RMSE and $d$-index were more or, less the same under both treatments and simulation period.

\section{Model application}

Effect on canopy height: The effect of human urine treatment $\left(T_{1}\right)$ on canopy height during the first 39 DAP showed that although there was some morphological difference to $\left(T_{0}\right)$, this was not significant $(p<0.01)$. The canopy height under both treatments during this vegetative stage was similar to the calibrant Y2015 at about $0.2 \mathrm{~m}$. Canopy height increased thereafter to about $0.6 \mathrm{~m}$ for both treatments. On average, the canopy height under $\mathrm{T}_{1}$ 40-60 DAP was 5-12\% higher than both under $T_{0}$ or that of the calibrant (Figure 1). This gain in canopy height as shown by genetic coefficient (RHIGHT) could be attributed to the continued growth during vegetative stage enhanced by the application of human urine. This was between 68-79 $\mathrm{cm}$ under $\mathrm{T}_{1}$ and $62-72 \mathrm{~cm}$ under $\mathrm{T}_{0}$ (Table 3). On the contrary, findings by (Ndiso et al., 2018) while working on cowpea-maize intercrops showed that $\mathrm{N}$-application decreased cowpea canopy height than for maize. The $\mathrm{N}$-application enhanced canopy height in maize giving it a competitive advantage by shading the cowpea plants (Dahmardeh et al., 2010). This, therefore reduced photosynthetic activity of the cowpea intercrop. Although not part of our investigation, the combined effects of such macronutrients like phosphorous, potassium as well as other micronutrients contained in the urine $\left(T_{1}\right)$ must have enhanced canopy growth relative to $T_{0}$. Such positive effects on biomass increase in okra plants was reported by (Akpan-Idiok et al., 2012); and on corn by (Araújo et al., 2015).

Effect on pod $\mathrm{nr}$ per $\mathrm{m}^{2}$ : The CROPGRO cowpea model overpredicted and gave high estimates of the pod $\mathrm{nr} / \mathrm{m}^{2}$ under both $\mathrm{T}_{0}$ and $T_{1}$ conditions (Figure 2). Rapid pod $\mathrm{nr} / \mathrm{m}^{2}$ increase for $T_{0}$ was between 55 to 61 DAP while this was between 60 to 65 DAP for
$T_{1}$. Both slightly increased at a decreasing rate till maximum pod $\mathrm{nr} / \mathrm{m}^{2}$ was reached at 75 and 82 for $\mathrm{T}_{0}$ and $\mathrm{T}_{1}$ respectively, at 80 DAP. Results of our study are consistent with those of (Ton and Anlarsal, 2018) who however, used different plant densities and genotypes. The pod $\mathrm{nr} / \mathrm{m}^{2}$ was affected by application of human urine, but not the time for pod setting that apparently should have been further delayed due to enhanced vegetative growth under $\mathrm{T}_{1}$. Similar observation in increase in $\mathrm{pod} \mathrm{nr} / \mathrm{m}^{2}$ after $\mathrm{N}$-application was reported by (Elowad and Hall, 1987).

The observed and simulated pod $\mathrm{nr} / \mathrm{m}^{2}$ clustered slightly above the $1: 1$ line. The size of RMSE for $T_{0}$ and $T_{1}$ were 17 and 37 and $d$ -indices at 0.54 and 0.55 , respectively, indicating that the model did not explain most of the variations in either cases. In Year 5, the observed and simulated pod $\mathrm{nr} / \mathrm{m}^{2}$ under $\mathrm{T}_{0}$ clustered more closer to the 1:1 line and gave better prediction. This reduction in pod $\mathrm{nr} / \mathrm{m}^{2}$ could be due to increased $\mathrm{N}$ fixation resulting from accumulation of $\mathrm{N}$ in the soil caused by additional application of human urine especially prior to flowering.

Effect on Leaf Area Index (LAI): The development of the observed LAl appeared to be poorly simulated or, was overpredicted in the first 10-35 DAP just between the $2^{\text {nd }}$ and $5^{\text {th }}$ trifoliate stage at the time of intense vegetative growth, but well especially between 40-79 DAP just prior to flowering till physiological maturity. The LAI under $T_{1}$ was generally higher than $T_{0}$ for most part of the phenology while leveling out after physiological maturity at 82 DAP as in Figure 3. The steep decline in LAI at 60 DAP would suggest a reduction in overall transpiration surface of the plants due to increased senescence with subsequent defoliation. The model overpredicted the LAI. Figure 3 shows, the variability of LAI during different phenological stages. Observed and simulated effect of either treatments on LAI between 20-40 DAP was about 0.31, 0.34 and 0.3 for $T_{0}, T_{1}$ and calibrant respectively. The five-years model simulations and observations of the LAI for both treatments resulted in poor agreements especially during vegetative stages 14-40 DAP, but good agreement when compared to the calibrant 2015. Peak LAI values were reached during reproductive stage 40-60 DAP with gradual decline thereafter until physiological maturity. Model simulations during the five years for $T_{1}$ treatment predicted LAI values of between $26-35 \%$, while this was between 28-32.4\% for $\mathrm{T}_{0}$ when compared with calibrant of 2015 . The model simulation over predicted LAl values above 0.6 but underpredicted slightly above this value. Under both treatments 55-61 DAP, the maximum LAI ranged between 0.68 for $T_{0}$ to 0.88 for $T_{1}$. The overall agreement of the measured and simulated data (relative to the $1: 1$ line) was good with $r^{2}=0.57$ and $r^{2}=0.64$ for $T_{0}$ and $T_{1}$, respectively (Figure 3). The RMSE (0.19) with $d=0.26$ during the entire growth period for $T_{0}$ was slightly lower than that of $\mathrm{T}_{1}$ with RMSE (0.25) and $d=0.36$ indicating the slightly better LAl estimation under $T_{0}$ than under $T_{1}$. The results of this study revealed that application of diluted human urine throughout the vegetative and reproductive stages (27-70 DAP) had significant difference $(p<0.05)$ on LAI of $T_{1}$ than under $\mathrm{T}_{0}$. Human urine as fertilizer enhanced intense vegetative leaf 

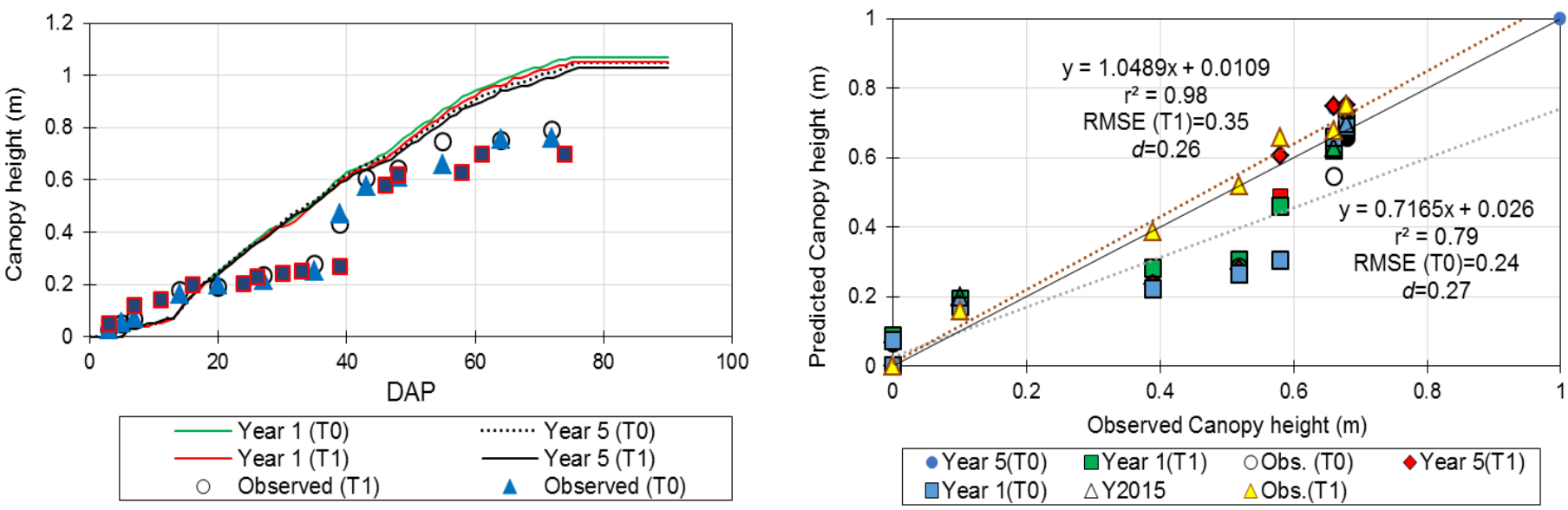

Figure 1. Comparison between observed and simulated canopy height $(m)$ of cowpea for $T_{0}$ and $T_{1}$ treatments.
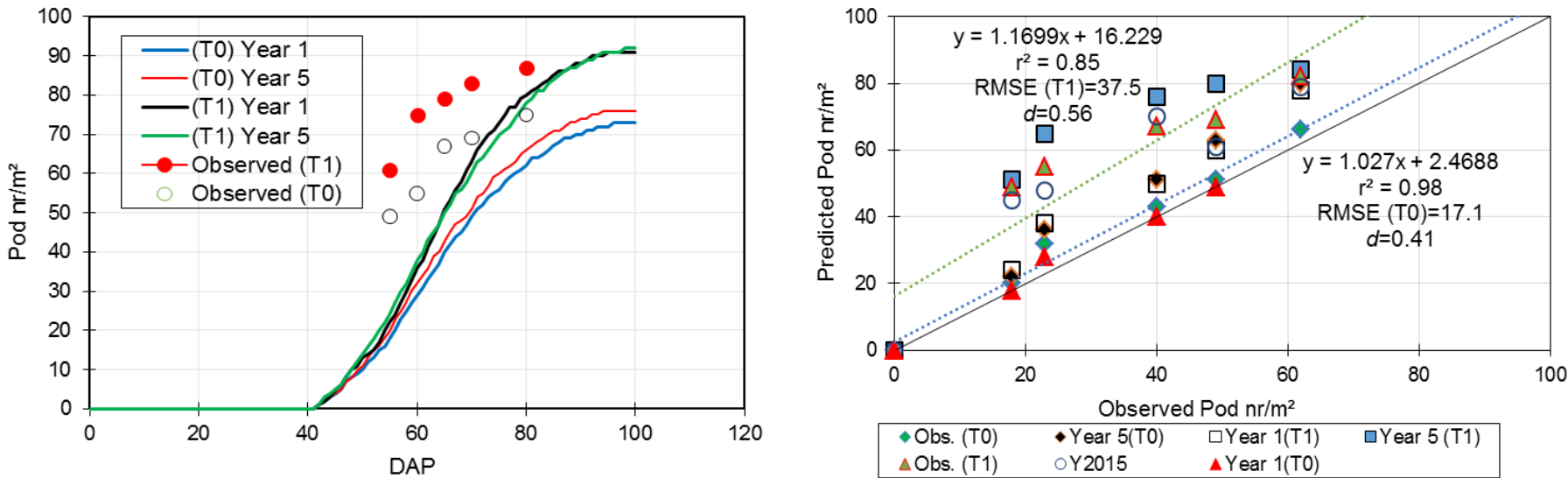

Figure 2. Comparison between observed and simulated pod $\mathrm{nr} / \mathrm{m}^{2}$ of cowpea for $T_{0}$ and $T_{1}$ treatments (a); solid line representing the 1:1 line while dotted blue and red represent regression lines for $T_{1}$ and $T_{0}$ respectively.
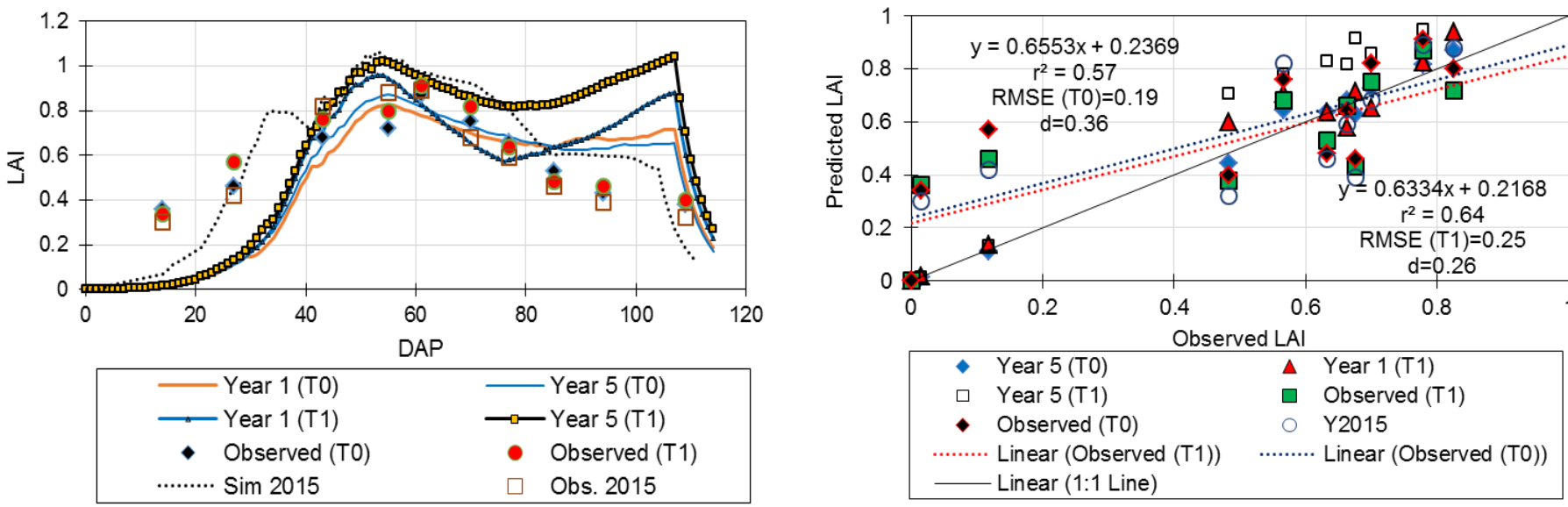

Figure 3. Comparing the observed and simulated LAl of cowpea.
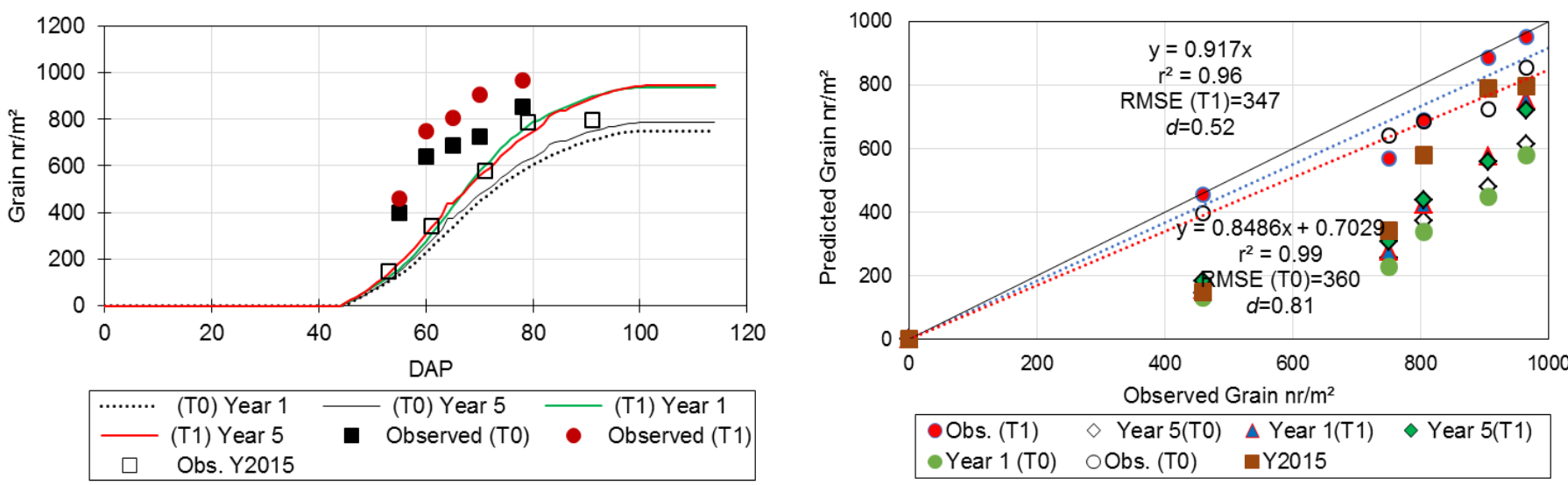

Figure 4. Comparing the observed and predicted grain $\mathrm{nr} / \mathrm{m}^{2}$ of cowpea under different treatments. 
growth, more light interception and hence increased protein photosynthetic activity and nutrient allocation during this period. In general, LAI under either treatment was not a constant variable, but varied at each stage of cowpea phenology. Although the cowpea cultivar UCR368 is a drought tolerant genotype and would withstand water stress periods during phenology, the decline in LAl can be assumed as a natural senescence process. Although, generally the CROPGROcowpea model may be used with relative accuracy, more calibration research especially for local dry conditions in South Sudan should be conducted.

Effect on Grain nr per $\mathrm{m}^{2}$ : Cowpea grain yield is a product of complex interacting genotypic and environmental factors (GxE). It is strongly and poly-genetically determined by several quantitative trait loci (QTL) that ensure yield output as a function of genetic variability and heritability irrespective of abiotic/biotic stresses the plant is subjected to. Several studies on cowpea have identified some QTL influencing such traits as pod length (Kongjaimun et al., 2012a); seed size (Kongjaimun et al., 2012b); 1000-seed/grain weight (TGW) and grain number per pod (Pan et al., 2017). The cowpea grain yield component is influenced by three main parameters: seeds/pod; pods/plant or grain number $/ \mathrm{m}^{2}$ and TGW. However, genotypic other than phenotypic expression as influenced by QTL may just be the dominant factor determining the cowpea grain yield. Moreover, finding correlation coefficients between both expressions would give an idea of the mutual interactions and whether, either of them is dominant, recessive or exclusive of the other (Srinivas et al., 2017). In this case, both genotypic coefficient of variation (GCV) as well as phenotypic coefficient of variation would indicate which of the expressions have a dominant effect on grain yield.

In our study, the model underpredicted the grain number $/ \mathrm{m}^{2}$ for both treatments with observed maximum values for $T_{1}$ and $T_{0}$ at 965 and 855, respectively which were significantly different at $p<0.05$ indicating a differentiated response of the cultivar to human urine application than without. On average, the simulated $T_{0}$ value for Years 1 to 5 was about 630 while this was about 767 for $T_{1}$. The five-years simulations under $T_{1}$ agreed well with calibrated values of 2015 but significantly higher $(p<0.05)$ than the simulations under $T_{0}$. The RMSE between the simulated and observed grain number per $\mathrm{m}^{2}$ under $T_{0}$ and $T_{1}$ was 360 and 347, respectively, with the relative error margin ranging between 8 and $13 \%$ for $T_{0}$ and only about $7 \%$ for $T_{1}$. The RMSE of the observed grain number per $\mathrm{m}^{2}$ with the calibrant Y2015 ranged between 5 and 19\% for $\mathrm{T}_{0}$ and $\mathrm{T}_{1}$, respectively. This wide RMSE range of the calibrant Y2015 to T1 would indicate the significant effect $(p<0.05)$ diluted human urine had on grain number per $\mathrm{m}^{2}$. Afterall, the cowpea plants under $\mathrm{T}_{0}$ and $T_{1}$ were subjected to similar number of irrigation schedules and therefore, it follows that this wide RMSE range of the grain number $/ \mathrm{m}^{2}$ to the calibrant $\mathrm{Y} 2015$ is solely attributable to the effects of $\mathrm{T}_{1}$ (Figure 4).
Grain yield and urine fertilizer application

The observed grain number $/ \mathrm{m}^{2}$ for $\mathrm{T}_{0}, \mathrm{~T}_{1}$ and calibrant $\mathrm{Y} 2015$ were 855, 965 and 789, respectively. The difference between each treatment to the calibrant were 56 or $7.1 \%, 176$ or $18.2 \%$ for $\mathrm{T}_{0}$ and $T_{1}$, respectively. The results of the five-year simulation with CROPGRO cowpea showed that the grain number $/ \mathrm{m}^{2}$ under $\mathrm{T}_{1}$ treatment to the calibrant $\mathrm{Y} 2015$ was on average higher at around 944 or $15.8 \%$, while this was at about 785 for $T_{0}$, equal to or less than that of the calibrant Implications are that, both the observed and simulated results under $T_{1}$ were comparatively higher than those under $T_{0}$. This clearly underpins the long-term effects of human urine as fertilizer on grain number and consequently on cowpea yield. The results of our study confirm the findings of earlier studies on the positive effects on $\mathrm{N}$-application on pods $/ \mathrm{m}^{2}$, seed weight and yield of cowpea (Elowad and Hall, 1987). However, the presence of other macro- and micro- nutrients contained in the urine should not be underrated especially in influencing the phenology or morphological traits of cowpea.

\section{Conclusion}

The five-year (2015-2020) CROPGRO simulation results of cowpea on growth parameters and cultivar coefficients under both treatments found higher correlation coefficients $\left(r^{2}\right)$, with the observed and predicted values when measured in terms of the RMSE and $d$-indices. Whereas the canopy height under both treatments was underpredicted, the pod $\mathrm{nr} / \mathrm{m}^{2}$ and grain $\mathrm{nr} / \mathrm{m}^{2}$ were all overpredicted with LAl showing the best prediction results. The DSSAT-CROPGRO model calibration with Y2015 under $T_{1}$ was successful especially for both pod and grain number $/ \mathrm{m}^{2}$, but less satisfactory for LAI and canopy height. Despite these discrepancies, the CROPGRO model can be used in the long-term in predicting phenology, estimating yield and morphological traits of cowpea under the test conditions at the experimental site. This research study showed the positive benefits over 5 years, on the use of diluted human urine as a cheap N-fertilizer. However, there's still need to conduct further field and simulation tests on the long-term effects of $\mathrm{N}$-fertilizer application on cowpea phenology under the same site conditions that can be calibrated and validated.

\section{ACKNOWLEDGEMENTS}

The authors are thankful to the Department of Agricultural Sciences, College of Natural Resources and Environmental Studies (CNRES), University of Juba, for providing necessary research facilities. We are also grateful to the Norwegian Government through the NORHED Project for funding of research equipment.

\section{Conflict of interest}

No conflict of interest is declared by the authors.

Open Access: This is an open access article distributed under the terms of the Creative Commons Attribution 4.0 License, which permits unrestricted use, distribution, and reproduction in any medium, provided the original author(s) if the sources are credited. 


\section{REFERENCES}

Abayomi, Y.A. and Abidoye, T. O. (2009). Evaluation of cowpea genotypes for soil moisture stress tolerance under screen house conditions. African Journal of Plant Science, 3(10): 229-237.

Adekiya, A.O., Ojeniyi, S.O. and Owonifari, O.E. (2017). Effect of cow dung on soil physical properties, growth and yield of maize (Zea mays) in a tropical Alfisol. Scientia Agriculturae, 15 (2): 374-379.

Agele, S.O., Aiyelari, O.P. and Famuwagun, B.O.I.K. (2018). Growth and yield adaptation of cowpea varieties sown as early- and late-rainy season crop in the rainforest and derived savanna agroecologies of south-west Nigeria. JOJ Horticulture \& Arboriculture, 1(5): 555-575, https://doi.org/10.19080/JOJHA.2018.01.555575

Akpan-Idiok, A. U., Udo, I. A. and Braide, I. E. (2012). The use of human urine as an organic fertilizer in the production of okra (Abelmoschus esculentus) in South Eastern Nigeria. Resources, Conservation and Recycling, 62: 14-20, https://doi.org/10.1016/j.resconrec.2012.02.003

Andersson, E. (2016). Turning waste into value: using human urine to enrich soils for sustainable food production in Uganda. Journal of Cleaner Production, 96: 290-298.

Araújo, A.S.F., Lima, L.M., Melo, W.J., Santos, V.M. and Araujo, F.F. (2016). Soil properties and cowpea yield after six years of consecutive amendment of composted tannery sludge. Acta Scientiarum. Agronomy, 38(3): 407-413 https://doi.org/10.4025/actasciagron.v38i3.28281

Araújo, N.C., Amorim C. M., Oliveira, R., Meira, C.M.B.S. and Oliveira, S.J.C. (2015). Cultivo hidropônico de milho fertirrigado com urina humana como fonte $\begin{array}{llll}\text { alternativa de nutrientes. IRRIGA, } 20 & \text { (4): } 718 \text {, }\end{array}$ https://doi.org/10.15809/irriga.2015v20n4p718

Banterng, P., Hoogenboom, G., Patanothai, A., Singh, P, Wani, S. P., Pathak, P., Tongpoonpol, S., Atichart, S., Srihaban, P., Buranaviriyakul, S., Jintrawet, A and Nguyen, T.C. (2010). Application of the Cropping System Model (CSM)CROPGRO Soybean for Determining Optimum Management Strategies for Soybean in Tropical Environments. Journal of Agronomy and Crop Science, 196 (3), 231-242.

Bastos, E.A., Folegatti, MV., Faria, R.T., Júnior, A.S.A. and Cardoso, M.J. (2002). Simulation of growth and development of irrigated cowpea in Piauí State by CROPGRO model. Pesquisa Agropecuária Brasileira, 37(10): 1381-1387.

Boote, K.J., Mínguez, M.I. and Sau, F. (2002). Adapting the CROPGRO legume model to simulate growth of faba bean. Agronomy Journal, 94(4): 7453-756, https://doi.org/10.2134/agronj2002.0743

Dahmardeh, D., Ghanbari, A., Syahsar, B.A., and Ramrodi, M. (2010). The role of intercropping maize (Zea mays L.) and Cowpea (Vigna unguiculata L.) on yield and soil chemical properties. African Journal of Agricultural Research, 5(8): 631 - 636.

Elowad, H.O.A. and Hall, A.E. (1987). Influences of early and late nitrogen fertilization on yield and nitrogen fixation of cowpea under well-watered and dry field conditions. Field Crops Research, 15(3-4): 229-244, https://doi.org/10.1016/0378-4290(87)90012-8

Famine Early Warning Systems Network (FEWSNET), East Africa Monitor, November 20, 2018. http://fews.net/sites/default/files/documents/reports/ EA_Seasonal_Monitor_2018_11_20_final_0.pdf

Fatokun, C.A., Boukar, O. and Muranaka, S. (2012). Evaluation of cowpea (Vigna unguiculata (L.) Walp.) germplasm lines for tolerance to drought. Plant Genet. Resour. 10, 171-176, https://doi.org/10.1017/S1479262112000214

Goufo, P., Moutinho-Pereira J.M., Jorge, T.F., Correia, C.M., Oliveira, M.R., Rosa, E.A.S., António, C. and Trindade, H. (2017). Cowpea (Vigna unguiculata L. Walp.) Metabolomics: Osmoprotection as a physiological strategy for drought stress resistance and improved yield. Frontiers in Plant Science, 8:586, https://doi.org/10.3389/fpls.2017.00586

Halder, D., Panda, R.K., Srivastava, R.K. and Kheroar, S. (2017). Evaluation of the CROPGRO-Peanut model in simulating appropriate sowing date and phosphorus fertilizer application rate for peanut in a subtropical region of eastern India. The Crop Journal, 317-325, http://dx.doi.org/10.1016/j.cj.2017.02.005

Hasan, M.R., Akbar, M.A., Khandaker, Z.H. and Rahman, M.M. (2010). Effect of nitrogen fertilizer on yield contributing character, biomass yield and nutritive value of cowpea forage. Bangladesh Journal Animal Science, 39(1\&2): 83-88. http://dx.doi.org/10.3329/bjas.v39i1-2.9680

Hunt, L.A., Pararajasingham, S., Jones, J.W., Hoogenboom, G., Imamura, D.T. and Ogoshi, R.M. (1993). GENCALC: Software to facilitate the use of crop models for analyzing field experiments. Agronomy Journal, 85(5): 1090-
1095, https://doi.org/10.2134/agronj1993.00021962008500050025x

Jemo, M., Sulieman, S., Bekkaoui, F., Olomide, O.A. K., Hashem, A., AbdAllah, E.F., Alqarawi, A.A. and Tran, L.S.P. (2017). Comparative analysis of the combined effects of different water and phosphate levels on growth and biological nitrogen fixation of nine cowpea varieties. Frontiers in Plant Science, 8: 2111 https://doi.org/10.3389/fpls.2017.02111

Jones, J.W., Hoogenboom, G., Porter, C.H., Boote, K. J., Batchelor,W.D. and Hunt, L.A. (2003). The DSSAT cropping system model. Eurasian Journal of Agronomy, 18: 235-265, https://doi.org/10.1016/S1161-0301(02)00107-7

Kongjaimun, A., Kaga, A., Tomooka, N., Somta, P., Shimizu, T. and Shu, Y. (2012a). An SSR-based linkage map of yard long bean (Vigna unguiculata (L.) Walp. subsp. unguiculata Sesquipedalis group) and QTL analysis of pod length. Genome, 55: 81-92, https://doi.org/10.1139/G11-078

Kongjaimun, A., Kaga, A., Tomooka, N., Somta, P., Vaughan, D.A. and Srinives, P. (2012b). The genetics of domestication of yardlong bean, Vigna unguiculata (L.) Walp. ssp. unguiculata CV.-gr. sesquipedalis. Annals of Botany, 109: 11851200, https://doi.org/10.1093/aob/mcs048

Lomeling, D. and Abass, A.A. (2014). Variability of cone index on seedling emergence rate and growth establishment of cowpea in a sandy loam soil (Eutric Leptosol). International Journal of Sciences: Basic and Applied Research, 14(1): 34-48.

Lomeling, D., Kenyi, M.M., Abdelrahman, A.A., Otwari, S.M. and Khater, Y.M. (2014). Using the CROPGRO model to predict phenology of cowpea under rain-fed conditions. International Journal of Plant \& Soil Science, 3(7): 824-844, https://doi.org/10.9734/IJPSS/2014/9491

Lomeling, D., Modi, A.L., Kenyi, S.M., Kenyi, M.C., Silvestro, G.M. and Yieb, J.L.L. (2016a). Comparing the macro-aggregate stability of two tropical soils: Clay soil (Eutric Vertisol) and sandy loam soil (Eutric Leptosol). International Journal of Agriculture and Forestry, 6(4): 142-151, https://doi.org/10.5923/j.ijaf.20160604.02

Lomeling, D., Silvestro, G.M., Kenyi, M.C., Modi A.L., Kenyi, M.S. and Yieb, J.L.L. (2016b). Assessing the spatial-temporal variability of soil moisture content on cowpea phenology using the CROPGRO Cowpea Model. International Journal of Research in Agriculture and Forestry, 3(5): 6-18.

Ndiso, J.B., Chemining'wa, G.N., Olubayo, F.M. and Saha, H. M. (2018). Effect of $\mathrm{N}$-fertilizer application on soil moisture content, canopy temperature, growth and yield maize - cowpea intercrops. Journal of Advanced Studies in Agricultural, Biological and Environmental Sciences, 5(2): 62-78.

Nweke, I.A. and Nsoanya, L.N. (2015). Effect of cow dung and urea fertilization on soil properties, growth, and yield of cucumber (Cucumis sativus L.). Journal of Agriculture and Ecology Research International, 3(2): 81-88, https://doi.org/10.9734/JAERI/2015/14084

Nyatuame, N. and Nartey S. (2013). Effects of cocoa husk powder and cow dung on moisture content and infiltration rate of a sandy soil. International Journal of Soil Science, 8(2): 68-77, https://doi.org/10.3923/ijss.2013.68.77

Oliviera, E.C., Costa, J.M.N., Júnior, T.J.P., Ferreira, W.P.M., Justino, F.B. and Neves, L.O. (2012). The performance of the CROPGRO model for bean (Phaseolus vulgaris L.) yield simulation. Acta Scientiarum. Agronomy, 34(3): 239-246, https://doi.org/10.4025/actasciagron.v34i3.13424

Pan, L., Wang, N., Wu, Z., Guo, R., Yu, X., Zheng, Y., Xia, Q., Gui, S. and Chen, C. (2017). A high-density genetic map derived from RAD sequencing and its application in QTL analysis of yield-related traits in Vigna unguiculata. Frontiers in Plant Science, 8:1544, https://doi.org/10.3389/fpls.2017.01544

Pudasaini, K., Walsh, K. B., Ashwath, N., \& Bhattarai, T. (2014, August). Effects of biochar addition on plant available water of a loamy sandy soil and consequences on cowpea growth. In XXIX International Horticultural Congress on Horticulture: Sustaining Lives, Livelihoods and Landscapes (IHC2014): 1112 (pp. 357-364)

Ranasinghe, E.S.S., Karunarathne, C.L.S.M., Beneragama, C.K. and Wijesooriya, B.G.G. (2016). Human urine as a low cost and effective nitrogen fertilizer for bean production. Procedia Food Science, 6: 279-282, https://doi.org/10.1016/j.profoo.2016.02.055

Robinson, S., D’Croz, D.M., Islam, S., Cennachi, N., Creamer, B., Gueneau, A., Hareau, G., Kleinwechter, U., Mottaleb, K.., Nedumaran, S., Robertson, R., Rosegrant M.W., Sika, G., Sulser, T.B. and Wiebe, K. (2015). IFPRI Discussion Paper 01469, October 2015. Climate change adaptation in agriculture: Ex ante analysis of promising and alternative crop technologies using DSSAT and IMPACT.

Sene, M., Hijikata, N., Ushijima, K. and Funamizu, N. (2013). Effects of extra human urine volume application in plant and soil. International Research Journal of Agricultural Science and Soil Science, 3(6): 182- 191. 
Singh, S., Boote, K.J., Angadi, S.V., Grover, K., Begna, S. and Auld. D. (2016). Adapting the CROPGRO model to simulate growth and yield of spring safflower in semiarid conditions. Agronomy Journal, 108: 64-72, https://doi.org/10.2134/agronj15.0272

Souza, P.J.O.P., Farias, V.D. da S., De Lima, M.J.A., Ramos, T.F. and De Sousa. A.M.L. (2017). Cowpea leaf area, biomass production and productivity under different water regimes in Castanhal, Pará, Brazil. Rev. Caatinga, Mossoró, 30 (3): 748 - 759, https://doi.org/10.1590/1983-21252017v30n323rc

Srinivas, J., Kale, V.S. and Nagre, P.K. (2017). Correlation and path analysis study in cowpea [Vigna unguiculata (L.) Walp.] genotypes. International Journal of Current Microbiology and Applied Sciences, 6(6): 3305-3313, https://doi.org/10.20546/ijcmas.2017.606.388

Suliman, A.H. and Ahmed, F.E. (2010). Effect of water potentials on growth and yield of cowpea (Vigna Unguiculata [L] Walp). Research Journal of Agriculture and Biological Sciences, 6(4): 401-410.

Tampio, E., Salo, T. and Rintala, J. (2016). Agronomic characteristics of five different urban waste digestates. Journal of Environmental Management, 169: 293-302, http://dx.doi.org/10.1016/j.jenvman.2016.01.001
Tekwa, I.J., Olawoye, H.U. and Yakubu, H. (2010). Comparative effects of separate incorporation of cow dung and rice-husk materials on nutrient status of some lithosols in mubi, N.E. Nigeria. International Journal of Agriculture and Biological Science, 12: 857-860, http://www.fspublishers.org. Online: 18149596-09-239/AWB/2010/12-6-857-860

Ton, A. and Anlarsal, E. (2018). Effects of nitrogen fertilizer application on yield and yield components of different cowpea genotypes (Vigna unguiculata L), Fresenius Environmental Bulletin, 27; 5605-5609.

Willmott, C.J. Robeson, S.M. and Matsuura. K. (2012). A refined index of model performance. International Journal of Climatology, 32: 2088-2094, https://doi.org/10.1002/joc.2419

Zinyengere, K., Crespo, O., Hachigonta, S. and Tadross. M. (2015). Crop model usefulness in drylands of southern Africa: an application of DSSAT. South African Journal of Plant and Soil, Foundation for Education Science and Technology, 32 (2): 95-104.

Zinyengere, N., Crespo, O., Hachigonta, S. and Tadross, M. (2015). Crop model usefulness in drylands of southern Africa: an application of DSSAT. South African Journal of Plant and Soil, 32(2): 95-104. 